\title{
Application of Saccharomyces cerevisiae/Calcium Alginate Composite Beads for Cephalexin Antibiotic Biosorption from Aqueous Solutions
}

\author{
Lăcrămioara Rusu ${ }^{1}$, Cristina-Gabriela Grigoraș ${ }^{1}{ }^{*}$, Andrei-Ionuț Simion ${ }^{1}$, Elena Mirela Suceveanu ${ }^{1}$ (D), \\ Daniela Șuteu ${ }^{2}$ and Maria Harja ${ }^{3}$ (D)
}

1 Department of Chemical and Food Engineering, "Vasile Alecsandri" University of Bacău, 600115 Bacău, Romania; lacraistrati04@yahoo.com (L.R.); asimion@ub.ro (A.-I.S.); mirela.suceveanu@ub.ro (E.M.S.)

2 Department of Organic, Biochemical and Food Engineering, "Gheorghe Asachi” Technical University of Iași, 700050 Iași, Romania; danasuteu67@yahoo.com

3 Department of Chemical Engineering, "Gheorghe Asachi” Technical University of Iași, 700050 Iași, Romania; maria_harja06@yahoo.com

* Correspondence: cristina.grigoras@ub.ro

check for

updates

Citation: Rusu, L.; Grigoras, C.-G.; Simion, A.-I.; Suceveanu, E.M.; Șuteu, D.; Harja, M. Application of Saccharomyces cerevisiae/Calcium Alginate Composite Beads for Cephalexin Antibiotic Biosorption from Aqueous Solutions. Materials 2021, 14, 4728. https://doi.org/ $10.3390 /$ ma14164728

Academic Editor: Artur P. Terzyk

Received: 15 July 2021

Accepted: 17 August 2021

Published: 21 August 2021

Publisher's Note: MDPI stays neutral with regard to jurisdictional claims in published maps and institutional affiliations.

Copyright: (c) 2021 by the authors. Licensee MDPI, Basel, Switzerland. This article is an open access article distributed under the terms and conditions of the Creative Commons Attribution (CC BY) license (https:/ / creativecommons.org/licenses/by/ $4.0 /)$.

\begin{abstract}
Cephalexin (CPX) is recognized as a water pollutant, and it has been listed in a number of countries with a risk factor greater than one. Herein, the present work focused on the synthesis, characterization and biosorption capacity evaluation of Saccharomyces cerevisiae immobilized in calcium alginate as a biosorbent to remove CPX from aqueous solutions. Biosorbent was characterized by SEM and FTIR techniques. Batch biosorption experiments were conducted in order to evaluate the effect of the initial $\mathrm{pH}$, biosorbent dose and CPX initial concentration. The removal efficiency, in considered optimal conditions $(\mathrm{pH}=4, \mathrm{CPX}$ initial concentration $=30 \mathrm{mg} / \mathrm{L}$, biosorbent dose $=1 \mathrm{~g} / \mathrm{L})$ was $86.23 \%$. CPX biosorption was found to follow the pseudo-second-order kinetics. The equilibrium biosorption data were a good fit for the Langmuir model with correlation coefficient of 0.9814 and maximum biosorption capacity was $94.34 \mathrm{mg} / \mathrm{g}$. This study showed that the synthesized biosorbent by immobilization technique is a low-cost one, easy to obtain and handle, eco-friendly, with high feasibility to remove CPX antibiotic from aqueous solution. The findings of this study indicate that the biosorbents based on microorganisms immobilized on natural polymers have the potential to be applied in the treatment of wastewater.
\end{abstract}

Keywords: antibiotic; cephalexin; biosorption; Saccharomyces cerevisiae; calcium alginate; water treatment; kinetics models; adsorption isotherms

\section{Introduction}

Pollution of the environment by pharmaceuticals is a challenging issue [1-5]. In fact, the development of analytical techniques has allowed their quantification in different environmental matrices [6,7].

Numerous studies have reported that organic pollutants such as drugs can have adverse effects on various life forms [2,3].

These pollutants have a potential environmental risk, especially to water quality, and they also generate a number of toxic effects because these molecules are biologically active [1,8-10].

Antibiotics are a category of drugs consumed in large quantities worldwide, so they are found in different water categories (wastewater, surface water and groundwater) [2,11].

Drugs in general, and antibiotics in particular, cannot be removed in wastewater treatment plants, due to the fact that the involved processes are generally based on physical and biological processes. 
This fact leads to the drugs' presence in the effluents of the wastewater treatment plants [2,12], so implicitly to the contamination of water resources, which involves serious problems for the environment and human health, such as toxicity and/or generation of antibiotic-resistant bacteria [13].

Cephalexin (CPX) $\left(\mathrm{C}_{16} \mathrm{H}_{17} \mathrm{O}_{4} \mathrm{~N}_{3} \mathrm{~S} \cdot \mathrm{H}_{2} \mathrm{O}\right)$ is a first-generation cephalosporin antibiotic with molecular weight of $365.40 \mathrm{~g} / \mathrm{mol}$, that was approved by FDA in 1971. It is used for the treatment of diseases infection caused by bacteria such as Streptococcus pneumoniae, Staphylococcus aureus, Escherichia coli etc. [14,15].

Due to its wide spectrum of action, the consumption of cephalexin in the world is estimated at around $3000 \mathrm{t} /$ year [16].

Cephalexin has been detected in wastewater, sewage effluents, hospital effluents, surface water, in various concentrations between $5000 \mathrm{ng} / \mathrm{L}$ and $7.4 \mathrm{ng} / \mathrm{L}$ [17-20].

CPX has been listed in a number of countries with a risk factor greater than one due to its high potential to induce antimicrobial resistance in bacterial cells, leading to mutagenic and carcinogenic effects [21,22].

Additionally, a series of studies correlate the use of CPX-contaminated water with a number of symptoms such as diarrhea, skin irritation, nausea and stomach ache [23].

Thus, this antibiotic must be effectively removed before being discharged into the environment to avoid its negative impact.

The literature presents numerous technologies for CPX removal, which include adsorption, photocatalysis, electrocoagulation, nanotechnology, etc. [14].

Advanced oxidation processes have been used successfully for CPX removal, but these processes have a number of disadvantages, such as the generation of more toxic degradation products and high operating costs [24-27].

Among these processes, adsorption is an interesting option for CPX removal due to the fact that this process is simple, efficient and economical.

The numerous studies regarding the removal of CPX from aqueous solutions with different types of adsorbents have been mentioned in the literature in the last decade. Among these, we can cite:

Activated carbon obtained from different materials: biochar obtained from oil palm fiber [2]; original and $\mathrm{Cu}$ (II)/Fe(III) impregnated activated carbons developed from lotus stalks [28]; activated carbon nanoparticles prepared from vine wood [29]; activated carbon prepared from alligator weed [30]; walnut shell-based activated carbon [16]; Anthriscus sylvestris-derived activated biochar [31]; activated carbon (PPAC) derived from pomegranate peel [32]; activated carbons from Albizia lebbeck seed pods by microwaveinduced $\mathrm{KOH}$ and $\mathrm{K}_{2} \mathrm{CO}_{3}$ activations [33].

Nanomaterials: PPAC-ZnO and PPAC-nZVI nanocomposite using pomegranate peel [34]; boron nitride nanosheets [35]; $\mathrm{Cu}-\mathrm{Zn}$ bionanocomposite biosynthesized in secondary metabolic products of Aspergillus arenarioides EAN603 with pumpkin peels medium [36], and modified biochar supported Ag/Fe nanoparticles [37].

Zeolites: zeolite coating with magnetic $\mathrm{Fe}_{3} \mathrm{O}_{4}$ nanoparticles [38]; natural zeolite and zeolite coated with manganese oxide nanoparticles [39], and magnetic zeolite [40].

Other materials: octenyl succinic anhydride starch [1]; zirconium-based metal-organic framework [41]; phosphoric acid-activated chitin [23]; magnetic carbon obtained from poly (ethylene) and terephthalate (PET) wastes [42].

Studies on CPX biosorption on living/dead microorganisms/biomass are also presented, among which are bacterial consortium biomass (living and dead) [43]; non-living Chlorella sp., biomass [44]; mixed bacterial cell biomass (living cells) [45] and Bacillus subtilis living cells [46].

The main problem that arises when using microorganisms or biomass is the separation of supernatants, which leads to the conclusion that it is necessary to obtain biosorbents that are easy to handle and separate and at the same time environmentally friendly. 
Taking into account those mentioned above, immobilization or encapsulation of microorganisms or biomass on inert supports would be a viable solution. This fact was demonstrated in our previous study in the case of dyes biosorption [47].

To our knowledge, the use of biosorbents based on microbial biomass immobilized on natural polymers have not been previously investigated for the removal of CPX from water matrix.

Considering the negative impact of CPX on the environment and the use of the biosorption process as a removal method, this paper focused on the synthesis, characterization and biosorption capacity evaluation of Saccharomyces cerevisiae immobilized in calcium alginate beads as a biosorbent to remove CPX from aqueous solutions.

\section{Materials and Methods}

\subsection{Chemicals and Analytical Procedure}

All the chemicals (cephalexin (Cayman Chemical, Tallinn, Estonia), sodium hydroxide (Chempur, Piekary Śląskie, Poland), hydrochloride acid (Chemical Company, Iași, Romania), sodium alginate (Carl Roth, Karlsruhe, Germany), calcium chloride (Chempur, Piekary Śląskie, Poland), sodium chloride (Chemical Company, Iași, Romania), ethanol (Chemical Company, Iași, Romania)) required in the experiments were of analytical purity and were used without further purification.

Yeast strain of Saccharomyces cerevisiae was kindly donated by Rompak Company (Pașcani, Romania).

A stock solution of cephalexin (Figure 1) with a concentration of $500 \mathrm{mg} / \mathrm{L}$ was prepared by dissolving the reagent in distilled water and kept at $4{ }^{\circ} \mathrm{C}$ in a closed vessel.

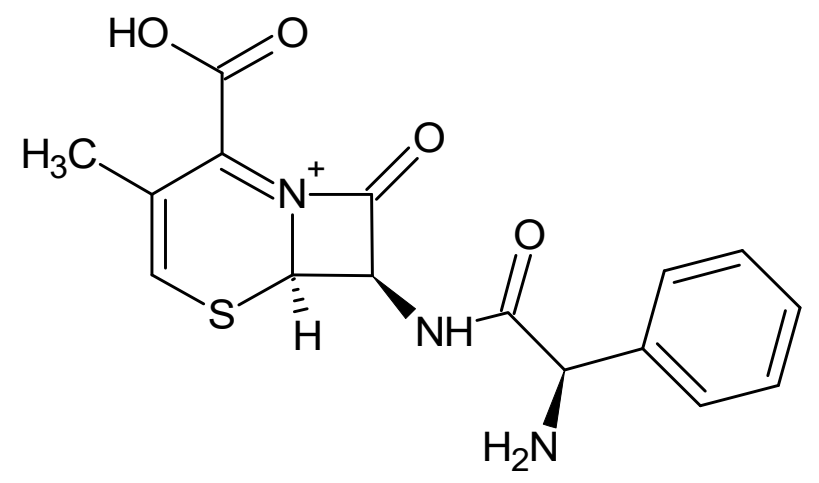

Figure 1. Chemical structure of cephalexin. (CAS 15686-71-2; molecular formula: $\mathrm{C}_{16} \mathrm{H}_{17} \mathrm{~N}_{3} \mathrm{O}_{4} \mathrm{~S}$; $\mathrm{MW}=347.40 \mathrm{~g} / \mathrm{mol})$.

For the calibration curve, $0.02,0.1,0.2,0.3,0.4,0.5$ and $0.6 \mathrm{~mL}$ of CPX stock solution were placed in a series of volumetric flasks and the volumes were adjusted to $10 \mathrm{~mL}$ in order to obtain concentrations ranging between $1 \mathrm{mg} / \mathrm{L}$ and $30 \mathrm{mg} / \mathrm{L}$. The samples absorbance was acquired at $260 \mathrm{~nm}$ with the help of a UV1280 spectrophotometer (Shimadzu, Tokyo, Japan). A calibration graph (absorbance vs. concentration) was plotted and a linear regression equation was recovered.

The other work solutions were obtained by appropriate dilutions. When necessary, $\mathrm{NaOH}(0.1 \mathrm{M})$ or $\mathrm{HCl}(0.1 \mathrm{M})$ were used to adjust the $\mathrm{pH}$.

\subsection{Biosorbent Preparation}

A certain amount of sodium alginate (for a $1 \%$ concentration) was introduced in a laboratory beaker containing hot water $\left(70^{\circ} \mathrm{C}\right.$ ) (Figure 2$)$ and mixed on a Nahita magnetic stirrer (Auxilab, Beriain, Spain) until complete dissolution. Inactivated dried Saccharomyces cerevisiae yeast was added in order to attain a final concentration of $2.5 \% \mathrm{~d}$.w. The mixing process was continued until a homogeneous suspension was obtained. The product was placed in a burette and dripped in a $2 \%$ calcium chloride solution. 


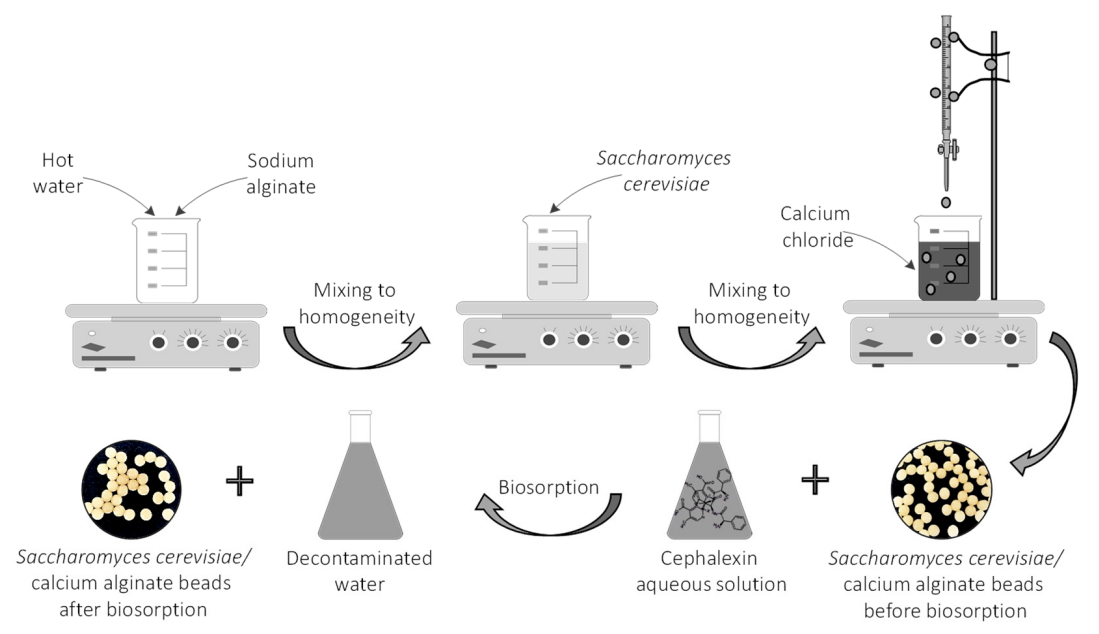

Figure 2. Schematic representation of the CPX biosorption process.

The resulting Saccharomyces cerevisiae/calcium alginate beads were separated, washed and then stored in calcium chloride solution for $24 \mathrm{~h}$ at $4{ }^{\circ} \mathrm{C}$. In all the biosorption experiments, they were used in their wet form.

\subsection{Biosorbent Characterization (Morphology, Functional Groups, Point of Zero Charge)}

The surface morphology and elemental composition of the synthesized Saccharomyces cerevisiae/calcium alginate beads were examined before and after the biosorption process by using a scanning electron microscope (SEM Quanta 200 3D (FEI Europe B.V., Eindhoven, Netherlands)) equipped with an energy-dispersive $\mathrm{X}$-ray system. The dried beads $\left(50^{\circ} \mathrm{C}\right.$, $2 \mathrm{~h}$ in an Air Performance AP60 hot air oven, (Froilabo, Paris, France) were fixed to stubs with double adhesive carbon discs. The analyses were carried out in normal secondary electron mode (SE) in low vacuum. The detection was ensured by a large field detector (LFD) at an accelerating voltage of $20 \mathrm{kV}$, a working distance of $15 \mathrm{~mm}$ and a spot size of 5 . The magnification range was between $1 \mathrm{~mm}$ and $10 \mu \mathrm{m}$.

The Fourier transform infrared (FT-IR) allowed the identification of the functional groups existing in the biosorbent material. Spectra were recorded with the attenuate total reflection (ATR) detection method before and after the biosorption process from 4000 to $400 \mathrm{~cm}^{-1}$ (32 scans co-added) with a resolution of $4 \mathrm{~cm}^{-1}$ on a Nicolet iS50 FT-IR spectrometer (Thermo Scientific, Dreiech, Germany) coupled with a built-in ATR accessory, DTGS detector and a $\mathrm{KBr}$ beam splitter. The ATR plate was cleaned with ethanol after each spectrum acquisition. Air was used for background spectrum reference, which was registered and compared with the anterior one.

The biosorbent point of zero charge was established by $\mathrm{pH}$ drift method $[34,48]$. Aliquots of $25 \mathrm{~mL}$ of a $0.1 \mathrm{M} \mathrm{NaCl}$ solution were used as background electrolyte. The initial $\mathrm{pH}$ values $\left(\mathrm{pH}_{\mathrm{i}}\right)$ were adjusted between 2 and 12 by small additions of $\mathrm{HCl}(0.1 \mathrm{M})$ or $\mathrm{NaOH}(0.1 \mathrm{M})$ and measured with a portable $\mathrm{pH}$ meter (Dostmann KLH9.1, 0-14 pH, Carl Roth, Karlsruhe, Germany), and $0.5 \mathrm{~g}$ of biosorbent were added to each solution. After $24 \mathrm{~h}$ of magnetically stirring at room temperature, the final $\mathrm{pH}$ values $\left(\mathrm{pH}_{\mathrm{f}}\right)$ were measured again. The $\mathrm{pH}_{\mathrm{pzc}}$ of the sample was determined from the curve $\mathrm{pH}_{\mathrm{f}}=\mathrm{f}\left(\mathrm{pH}_{\mathrm{i}}\right)$.

\subsection{Effect of Biosorption Parameters ( $p H$, Biosorbent Amount, CPX Initial Concentration)}

$\mathrm{CPX}(50 \mathrm{mg} / \mathrm{L})$ solutions with different $\mathrm{pH}(2-12)$ were put in contact with $1 \mathrm{~g}$ of biosorbent beads. Once the favorable $\mathrm{pH}$ value was established, the amount of the biosorbent was varied $(0.5-3 \mathrm{~g})$. After that, CPX concentration was changed between $10 \mathrm{mg} / \mathrm{L}$ and $80 \mathrm{mg} / \mathrm{L}$. For these determinations, the contact period was set at $12 \mathrm{~h}$.

Each time, volumes of $25 \mathrm{~mL}$ of CPX solution were used. The remaining CPX concentrations were calculated by reading the samples absorbance at the wavelength of $260 \mathrm{~nm}$ against the calibration curve. 
The CPX removal efficiency $(R, \%)$ and the biosorption capacity at equilibrium $\left(q_{e}, \mathrm{mg} / \mathrm{g}\right)$ were determined with the following equations:

$$
\begin{aligned}
& R=\frac{\left(C_{0}-C_{e}\right) \cdot 100}{C_{0}} \\
& q_{e}=\frac{\left(C_{0}-C_{e}\right) \cdot V}{m}
\end{aligned}
$$

where $C_{0}$ and $C_{e}$ are the initial and at equilibrium state concentrations $(\mathrm{mg} / \mathrm{L}) ; V$ is the $\mathrm{CPX}$ volume $(\mathrm{L})$ and $m$ is the amount of the biosorbent $(\mathrm{g})$.

\subsection{Kinetics and Equilibrium Isotherms}

Two kinetic models, namely pseudo-first-order (Equation (3)) and pseudo-secondorder (Equation (4)) were tested.

$$
\begin{gathered}
\log \left(q_{e}-q_{t}\right)=\log q e-\frac{k_{1}}{2.303} \cdot t \\
\frac{t}{q_{t}}=\frac{1}{k_{2} \cdot q_{e}^{2}}+\frac{t}{q_{e}}
\end{gathered}
$$

where $q_{t}$ and $q_{e}$ are the biosorption capacities of CPX at time $t$ and at equilibrium, $\mathrm{mg} / \mathrm{g}$; $t$ is the reaction time, minutes; $k_{1}$ and $k_{2}$ are the biosorption rate constants for pseudo-firstorder and pseudo-second-order kinetic models, respectively, $\min ^{-1}$.

In terms of equilibrium isotherms, Langmuir (Equation (5)) and Freundlich (Equation (6)) ones were considered to investigate the CPX biosorption on the prepared biosorbent.

$$
\begin{gathered}
\frac{C_{e}}{q_{e}}=\frac{1}{q_{m} \cdot K_{L}}+\frac{C_{e}}{q_{m}} \\
\log q_{e}=\log K_{F}+\frac{1}{n} \cdot \log C_{e}
\end{gathered}
$$

where $C_{e}$ and $q_{e}$ are the equilibrium concentration $(\mathrm{mg} / \mathrm{L})$ and equilibrium biosorption capacity $(\mathrm{mg} / \mathrm{g}) ; q_{m}$ is the maximum biosorption capacity $(\mathrm{mg} / \mathrm{g}) ; K_{L}$ is the Langmuir constant $(\mathrm{L} / \mathrm{g}) ; n$ and $K_{F}(\mathrm{mg} / \mathrm{g})$ are the Freundlich constants.

\section{Results and Discussion}

\subsection{Biosorbent Preparation}

For the biosorbent preparation, a homogeneous solution of sodium alginate in hot water was firstly obtained. The appropriate amount of Saccharomyces cerevisiae biomass was added and mixed for several hours. The suspension was then dropped from a burette into a calcium chloride solution. The biosorbent shape (Figure 3) depends on the alginate solution viscosity, calcium chloride collection solution concentration and temperature, and on the stirring speed. Spherical beads with a mean diameter of $3.32 \pm 0.12 \mathrm{~mm}$ and opaque, shiny appearance were obtained. Their aspect was stable even after one week of storage at $4{ }^{\circ} \mathrm{C}$.

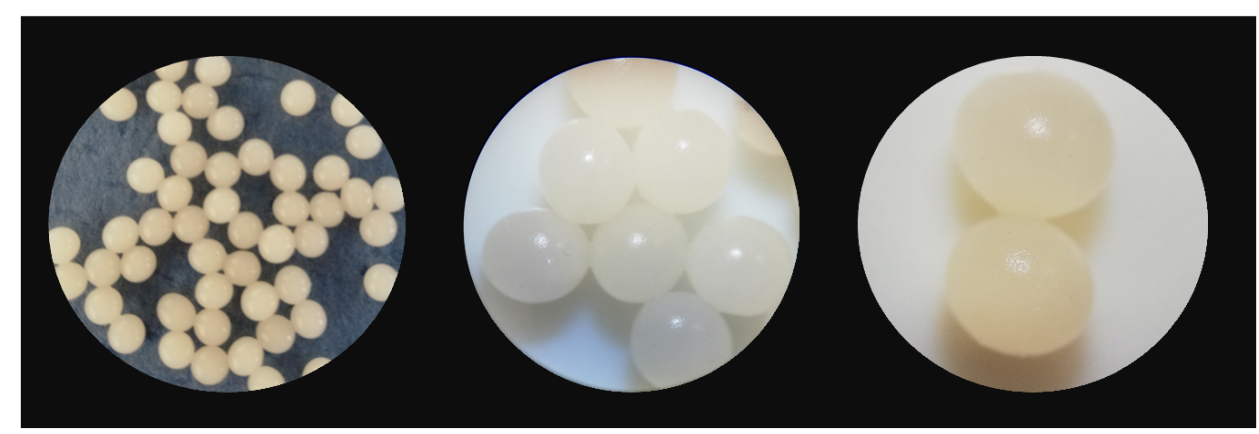

Figure 3. Saccharomyces cerevisiae/calcium alginate beads. 


\subsection{SEM and FT-IR Analyses of the Biosorbent}

Scanning electron microscopy served to study the Saccharomyces cerevisiae/calcium alginate beads morphology (Figure 4A). The internal mesoporous structure can be easily observed. SEM pictures show that the microorganism was homogeneously distributed in the polymer matrix, confirming that the immobilization process successfully took place. When analyzing the SEM photographs presented in Figure 4B, some differences can be noted, among them being the fact that the particles were smoother after CPX biosorption. The biosorbent elemental analysis revealed higher percentages of carbon and nitrogen at the end fact that sustains the antibiotic removal by biosorption on the material surface. The difference between the amount of calcium before and after the biosorption can be explained by the fact that most of the calcium ions were removed in the washing preliminary step required before the biosorbent-adsorbate contact.
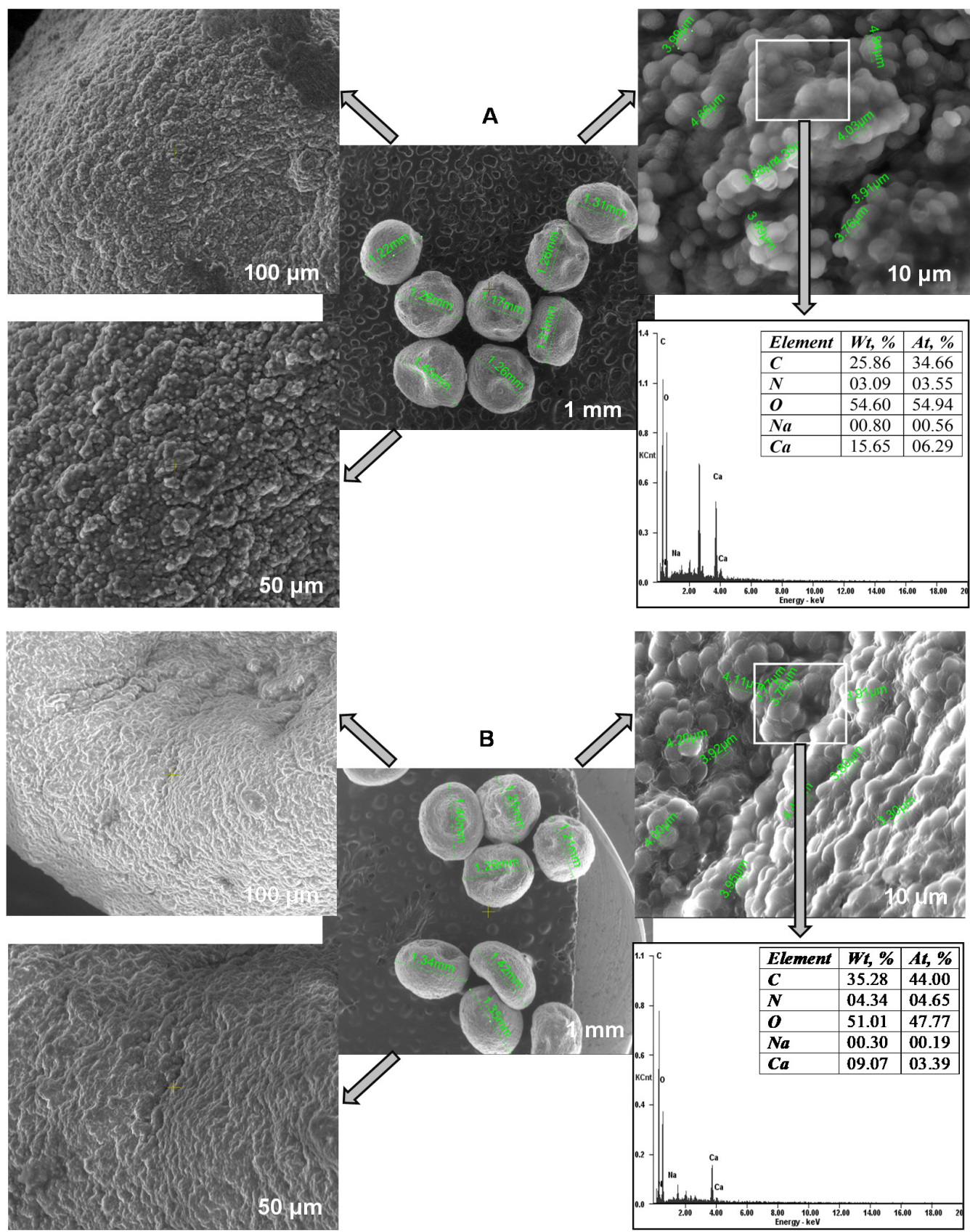

Figure 4. SEM images and EDAX analyses of the biosorbent before (A) and after biosorption (B). 
Figure 5 depicts the Saccharomyces cerevisiae/calcium alginate beads FT-IR spectra. Before the biosorption, the vibrations characteristics ranged between 3200 and $2900 \mathrm{~cm}^{-1}$ and between 1600 and $400 \mathrm{~cm}^{-1}$. The broad peak recorded at $3273 \mathrm{~cm}^{-1}$ was specific to the $\mathrm{OH}$ group while the sharp one of $2920 \mathrm{~cm}^{-1}$ can be assigned to $\mathrm{C}-\mathrm{H}$ stretching. Signals of $1623,1540,1418,1239 \mathrm{~cm}^{-1}$ and $1025 \mathrm{~cm}^{-1}$ can be attributed to $\mathrm{C}=\mathrm{O}$, amide II $(\mathrm{N}-\mathrm{H}$ join with $\mathrm{C}-\mathrm{N})$, asymmetric $\mathrm{COO}^{-}$and $\mathrm{C}-\mathrm{O}$ stretching, respectively $[49,50]$. The peak registered at $815 \mathrm{~cm}^{-1}$ was specific to carbohydrates $C-H$ vibration. At $1646 \mathrm{~cm}^{-1}$ a vibration of amide was recorded; at $1635 \mathrm{~cm}^{-1}$ a peak of carbonyl group $\mathrm{C}=\mathrm{O}$ can be remarked. At $1362 \mathrm{~cm}^{-1}$, at $1313 \mathrm{~cm}^{-1}$ and at $1238 \mathrm{~cm}^{-1}$, stretching for $\mathrm{C}-\mathrm{OH}$, for amide III (proteins) and for $\mathrm{PO}_{2}$-asymmetric and symmetric (phosphorylated proteins, phospholipids) can be distinguished [51,52].

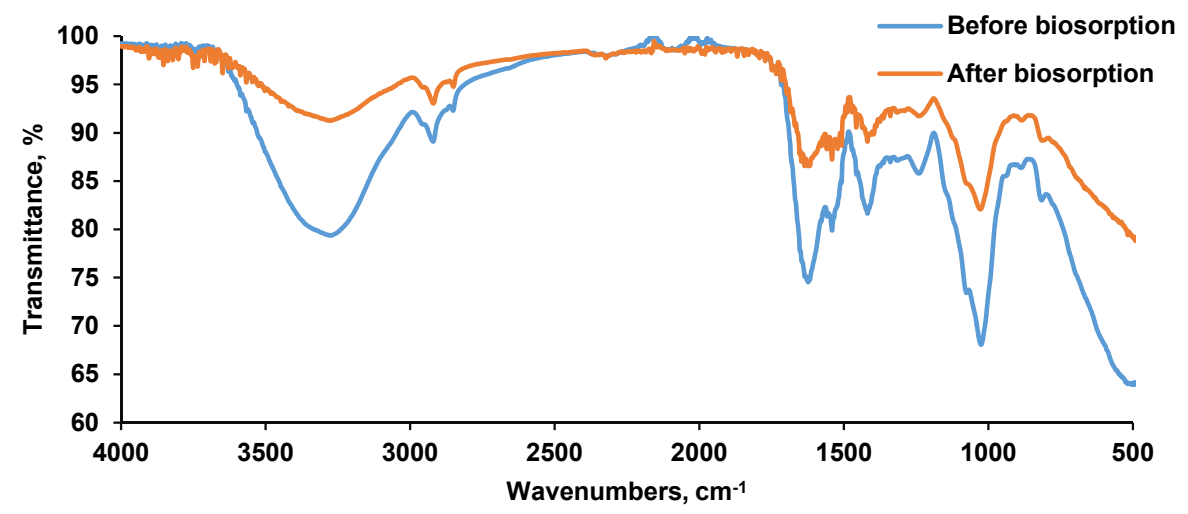

Figure 5. FT-IR spectra of the biosorbent before and after biosorption.

After the biosorption, some of the above mentioned peaks gained in intensity. As an example, the signal of $3273 \mathrm{~cm}^{-1}$ specific for hydroxyl group gained in intensity from 79.352 to $91.246 \%$; the signal of $2920 \mathrm{~cm}^{-1}$ specific for $\mathrm{C}-\mathrm{H}$ band gained in intensity from 89.095 to $93.039 \%$; the signal of $1623 \mathrm{~cm}^{-1}$ specific for $\mathrm{C}=\mathrm{O}$ stretching gained in intensity from $74.535 \%$ to $86.547 \%$; the signal of $1540 \mathrm{~cm}^{-1}$ specific for amidic group gained in intensity from $79.877 \%$ to $87.230 \%$ and the signal of $1418 \mathrm{~cm}^{-1}$ specific for carboxylic group gained in intensity from $81.642 \%$ to $89.085 \%$. These results reveal that the CPX was retained on the biosorbent material.

\subsection{Biosorbent Point of Zero Charge $\left(p H_{P Z C}\right)$}

At given work conditions, the point of zero charge (also called the isoelectric point) is the $\mathrm{pH}$ value at which there are equal amount of positive and negative charges on the biosorbent surface [53]. When the $\mathrm{pH}$ is lower than the $\mathrm{pH}_{\mathrm{PZC}}$, the biosorbent is considered positively charged. On the contrary, when $\mathrm{pH}$ is above $\mathrm{pH}_{\mathrm{PZC}}$, the biosorbent is in negative charge. Figure 6 illustrates the difference between the initial and final $\mathrm{pH}$ values.

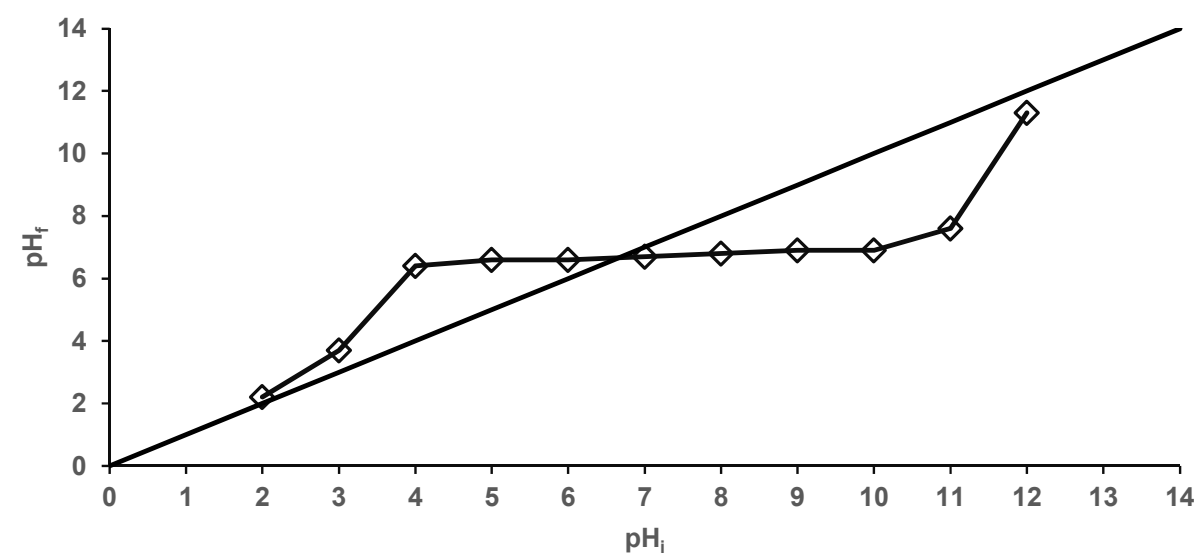

Figure 6. Biosorbent point of zero charge. 
It can be seen that the $\mathrm{pH}_{\mathrm{PZC}}$ value of the prepared material was 6.6, indicating a rather neutral character. This observation is consistent with the one published by de Rossi et al. [48], which reported that beads obtained from residual Saccharomyces cerevisiae biomass immobilized on calcium alginate had a $\mathrm{pH}_{\mathrm{PZC}}$ of 7.0.

\subsection{Effect of $p H$}

One of the main factors affecting the biosorption process is represented by the initial $\mathrm{pH}$ value of the working solution (Figure 7).

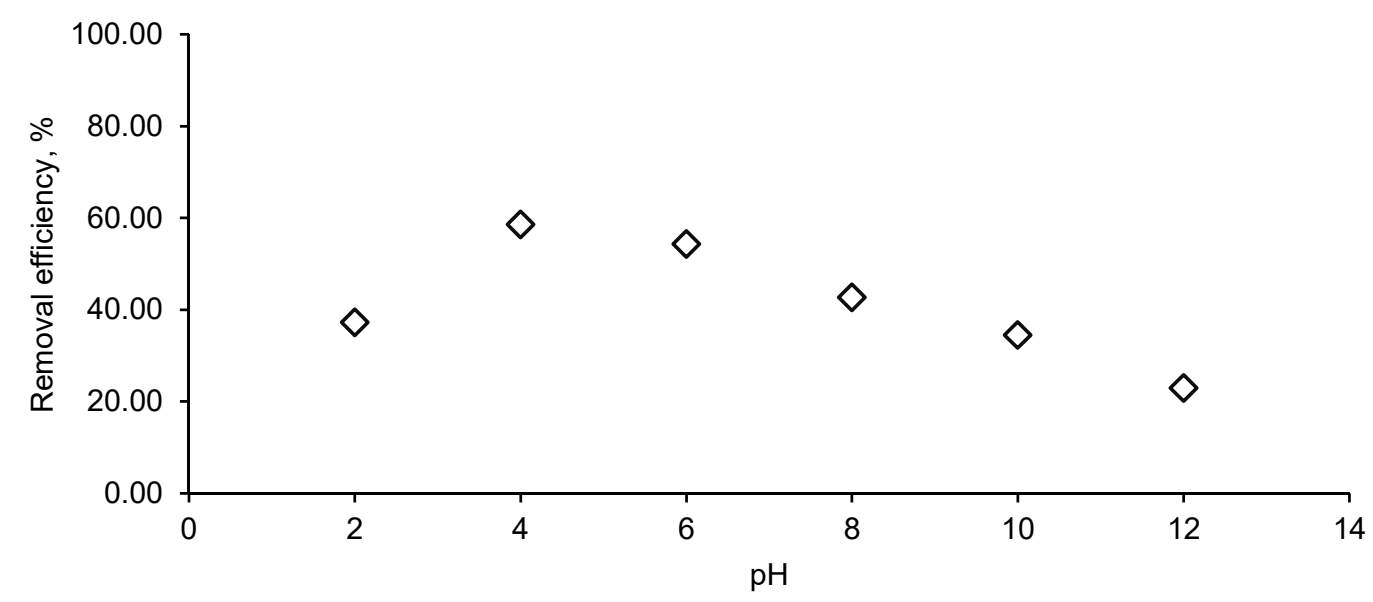

Figure 7. $\mathrm{pH}$ influence on CPX removal efficiency. (CPX solution volume: $25 \mathrm{~mL}$; CPX initial concentration: $50 \mathrm{mg} / \mathrm{L}$; biosorbent dose: $1 \mathrm{~g} / \mathrm{L}$ ).

In our case, the CPX removal efficiency had the highest value in acidic media (58.56\%) at $\mathrm{pH} 4$ and the lowest one in the alkaline environment (22.92\% at $\mathrm{pH} 12)$. In correlation with $\mathrm{pH}_{\mathrm{PZC}}, \mathrm{pH}$ offers information about the biosorption process. At a $\mathrm{pH}$ inferior to $\mathrm{pH}_{\mathrm{PZC}}$, the biosorbent possesses a positive charge and can interact with the negative charges of the antibiotic, while at a $\mathrm{pH}$ higher than $\mathrm{pH}_{\mathrm{PZC}}$, interactions take place between the negative biosorbent surface and the medicine positive charges.

At the same time, the functional groups existing in CPX structure lead to the existence of two pKa values: $\mathrm{pKa}_{1}=2.56$ and $\mathrm{pKa}_{2}=6.88$. Below $\mathrm{pKa}_{1}, \mathrm{CPX}$ is in its cationic form, between $\mathrm{pKa}_{1}$ and $\mathrm{pKa}_{2}$ it is in zwitterionic form and after $\mathrm{pKa}_{2}$ in its anionic form. Therefore, the high value recorded at $\mathrm{pH} 4$ for the biosorption is explained by the electrostatic attraction between the biosorbent positive surface and the CPX zwitterionic form. Similar details have been described by other researchers $[29,35,39,54]$ who studied the $\mathrm{CPX}$ biosorption alone or in combination with other drugs on different types of biosorbent materials. They also reported that at a strong acid or alkaline $\mathrm{pH}$, the biosorption capacity is lower due to competition between the hydrogen ions or hydroxyl groups, respectively with CPX ions for the biosorbent binding sites.

\subsection{Effect of Biosorbent Dosage}

Various biosorbent amounts $(0.5,1,1.5,2,2.5,3 \mathrm{~g} / \mathrm{L})$ were added to $25 \mathrm{~mL}$ of CPX solution with a concentration of $50 \mathrm{mg} / \mathrm{L}$ at $\mathrm{pH} 4$. As shown in Figure 8 , the removal efficiency increased from $34.43 \%$ for a biosorbent dose of $0.5 \mathrm{~g} / \mathrm{L}$ to more than $50 \%$ when the biosorbent concentration was of $1 \mathrm{~g} / \mathrm{L}$, and began to decrease when the biosorbent was used in higher quantities.

Comparable observations were drawn by Samarghandi et al. [39], who focused on the removal of CPX from aqueous solution by using zeolites. They identified that the increase in the biosorbent quantity ensures a larger surface area for biosorption and that after a certain biosorbent dose, aggregation of available binding sites appears, leading to a lower removal efficiency. Bangari et al. [35] presented a similar interpretation for the influence of the biosorbent material dosage on the biosorption of three different antibiotics, CPX 
being one of them. As a consequence, for further experiments, a biosorbent concentration of $1 \mathrm{~g} / \mathrm{L}$ was considered as optimum.

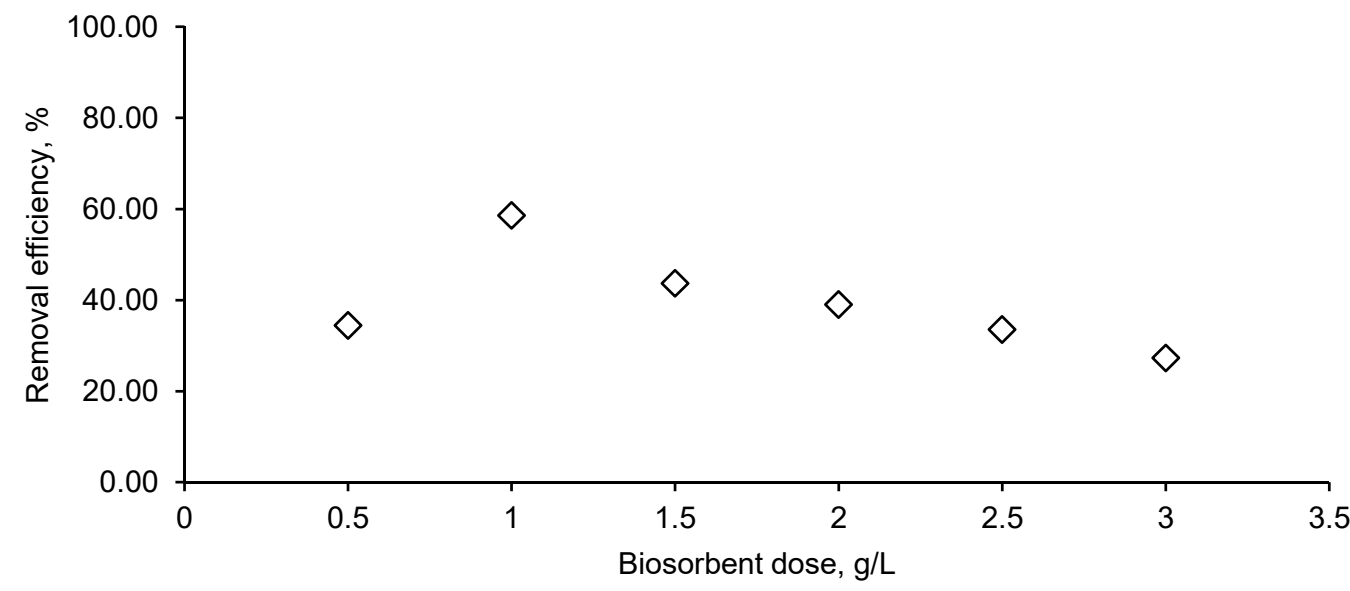

Figure 8. Biosorbent dose influence on CPX removal efficiency (CPX solution volume: $25 \mathrm{~mL}$; $\mathrm{CPX}$ initial concentration: $50 \mathrm{mg} / \mathrm{L}$; $\mathrm{CPX}$ initial solution $\mathrm{pH}: 4$ ).

\subsection{Effect of CPX Initial Concentration}

Volumes of $25 \mathrm{~mL}$ of CPX solution with concentrations between $10 \mathrm{mg} / \mathrm{L}$ and $60 \mathrm{mg} / \mathrm{L}$ with $\mathrm{pH}$ adjusted at four were put in contact with $1 \mathrm{~g} / \mathrm{L}$ of biosorbent for $12 \mathrm{~h}$. Figure 9 displays the influence of $\mathrm{CPX}$ initial concentration on the biosorption process. At low values $(10 \mathrm{mg} / \mathrm{L}$ and $20 \mathrm{mg} / \mathrm{L})$, the antibiotic was almost completely removed while an augmentation of CPX concentration at $80 \mathrm{mg} / \mathrm{L}$ led to a removal efficiency of only $38.61 \%$. The same behavior was disclosed by Nazari et al. [16,55], who conducted their studies of CPX biosorption on activated carbon obtained from walnut shell and showed that the retention is more favorable at a reduced concentration.

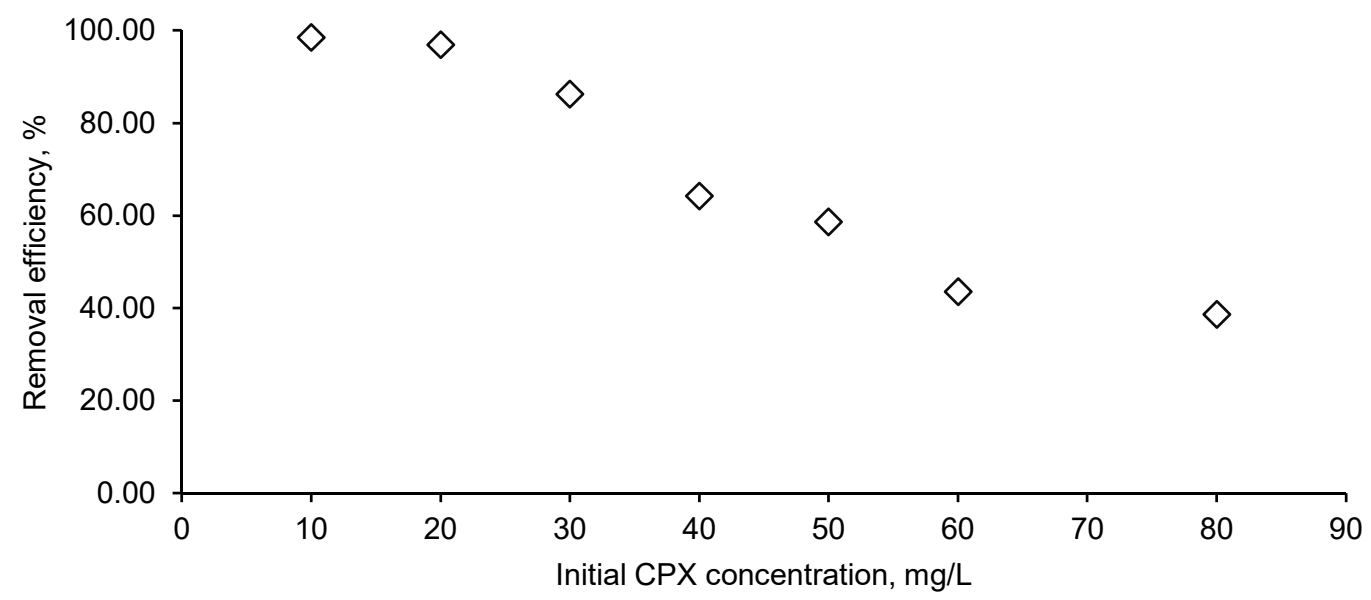

Figure 9. Initial CPX influence on the removal efficiency (CPX solution volume: $25 \mathrm{~mL}$; $\mathrm{CPX}$ initial solution $\mathrm{pH}$ : 4; biosorbent dose: $1 \mathrm{~g} / \mathrm{L})$.

\subsection{Biosorption Kinetics}

For the kinetic study, $1 \mathrm{~g} / \mathrm{L}$ biosorbent was introduced in a flask containing $50 \mathrm{~mL}$ of $\mathrm{CPX}$ aqueous solution with a concentration of $30 \mathrm{mg} / \mathrm{L}$ at $\mathrm{pH}$ set at four. Every 5 to $10 \mathrm{~min}$ samples were collected and their antibiotic amount determined.

In order to analyze the rate controlling step in the elimination of CPX, two kinetic models, the pseudo-first-order and pseudo-second-order were explored (Figure 10). 

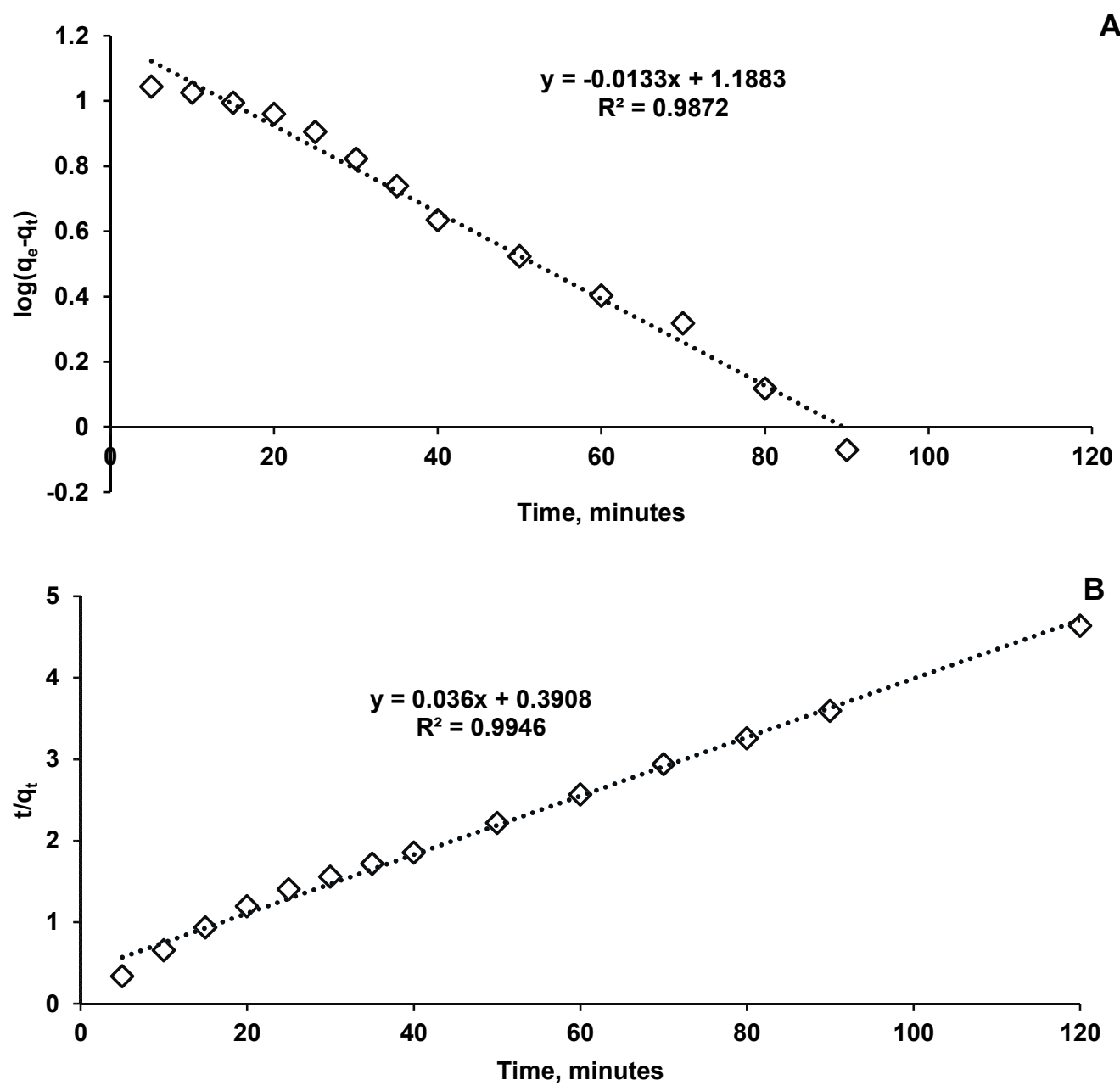

Figure 10. Pseudo-first-order (A) and pseudo-second-order (B) kinetics models of CPX biosorption process.

Biosorption kinetic parameters of CPX on Saccharomyces cerevisiae/calcium alginate beads were calculated using the equations presented in Figure 10 (Table 1). The correlation coefficients values revealed that the pseudo-second-order model better fit the experimental data than the pseudo-first order one. In the last situation, even though until $90 \mathrm{~min}^{2}$ is 0.9872 when the model is extended, for all the 120 min considered, a decrease in the correlation coefficient can be detected. Taking into account the kinetic model, it can be considered that chemical interaction between the biosorbent and the antibiotic represents one of the explanations of the biosorption process mechanism, which is also in agreement with the findings of Zhao et al. [41], who sustained the chemisorption process of CPX on a synthetic biosorbent material.

Table 1. Biosorption kinetic parameters of CPX on Saccharomyces cerevisiae/calcium alginate beads.

\begin{tabular}{ccc}
\hline Parameter & Pseudo-First-Order Kinetic Model & Pseudo-Second-Order Kinetic Model \\
\hline $\mathrm{q}_{\mathrm{e}}(\mathrm{mg} / \mathrm{g})$ & 15.4276 & 25.89 \\
\hline $\mathrm{k}_{1}\left(\mathrm{~min}^{-1}\right)$ & 0.0306 & - \\
\hline $\mathrm{k}_{2}\left(\mathrm{~min}^{-1}\right)$ & - & 0.2529 \\
\hline $\mathrm{R}^{2}$ & 0.9872 & 0.9946 \\
\hline
\end{tabular}




\subsection{Biosorption Isotherms}

The biosorption can be described as a process in which the adsorbate is transferred on the biosorbent material. The retention mechanisms consist of chemical and physical adsorption represented by formation of chemical bonds and by interactions such as Van der Waals and ion exchange, respectively [56], and are the subject of different modelling investigations. Langmuir and Freundlich models are known as the most used for study of the experimental data at equilibrium.

In our research, the collected data fit better on the Langmuir model $\left(R^{2}=0.9814\right)$ (Figure 11A) than on the Freundlich one $\left(R^{2}=0.9485\right)$ (Figure 11B). These biosorption isotherms indicated the interaction of the adsorbate with the tested biosorbent providing valuable information on its biosorption capacity. Langmuir isotherm is based on hypotheses such as monolayer biosorption, homogeneity of biosorption sites distribution, constancy of biosorption energy and insignificant interactions between the molecules to be adsorbed. Freundlich isotherm stipulates that the biosorption phenomenon is a multilayer one and that it occurs on heterogeneous surfaces.
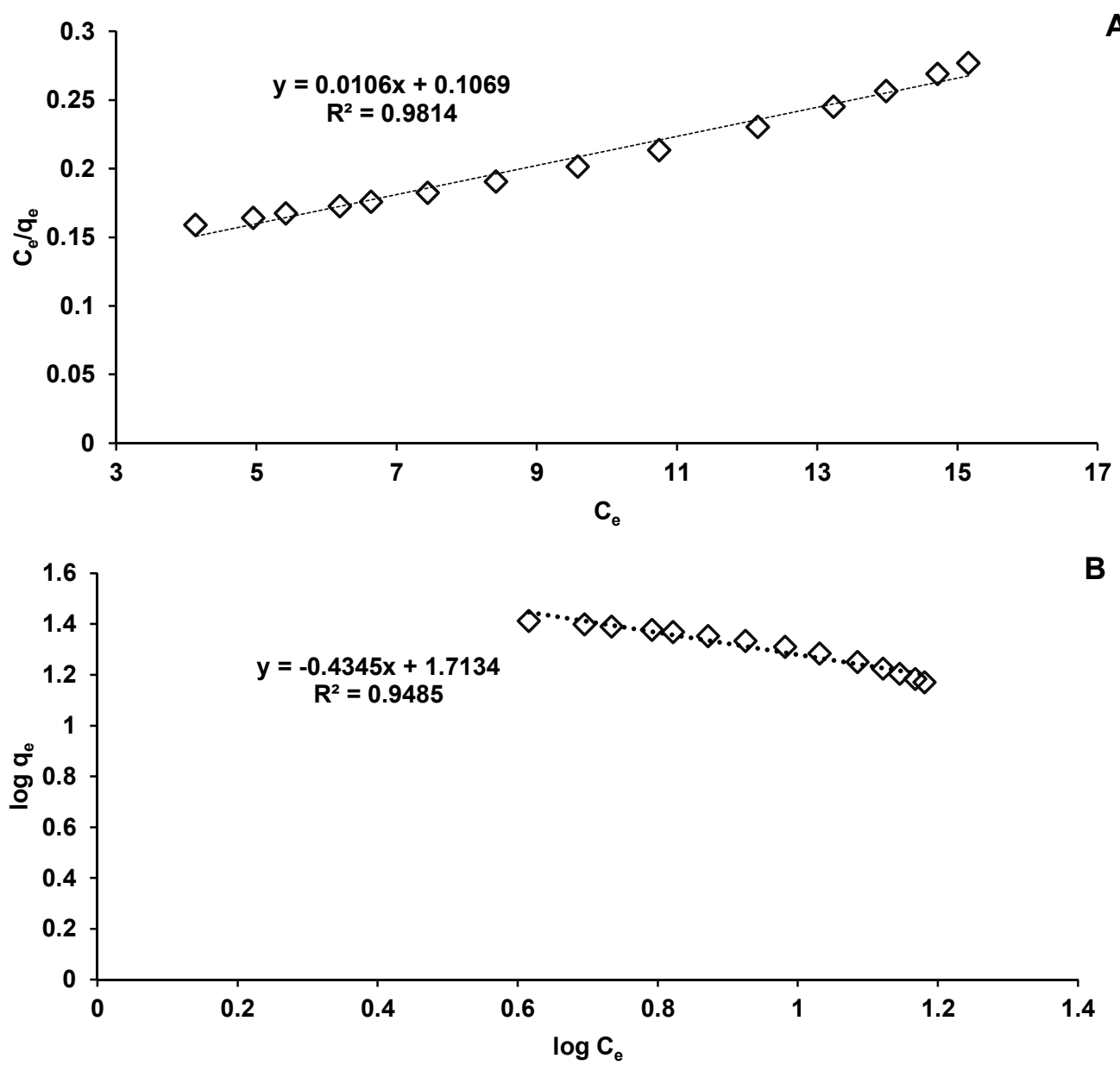

Figure 11. Langmuir (A) and Freundlich (B) isotherms of CPX biosorption process.

Table 2 presents the biosorption parameters released from the Langmuir and Freundlich equations according to Figure 11.

For the first mentioned isotherm model, the maximum adsorption capacity of $\mathrm{CPX}$ on Saccharomyces cerevisiae/calcium alginate beads was of $94.34 \mathrm{mg} / \mathrm{g}$, significantly lower than that calculated by Bangari et al. [35], who conducted absorption of CPX on boron nitride nanosheets, but higher than that indicated by Acelas et al. [57], who used palm oil fiber as a precursor for an adsorbent material able to remove $\mathrm{CPX}$ from aqueous solutions. 
Immobilization of microorganisms creates a better contact between the biosorbent and CPX molecules. As presented in Table 3, the values obtained for the maximum biosorption capacity predicted by the Langmuir model were higher than those reported in the literature for living and non-living microorganism/biomass in their free state.

Table 2. Langmuir and Freundlich models of CPX biosorption process on Saccharomyces cerevisiae/calcium alginate beads.

\begin{tabular}{ccc}
\hline Parameter & Langmuir Model & Freundlich Model \\
\hline $\mathrm{Q}_{\mathrm{m}}(\mathrm{mg} / \mathrm{g})$ & 94.34 & - \\
\hline $\mathrm{k}_{\mathrm{L}}(\mathrm{L} / \mathrm{mg})$ & 0.9915 & - \\
\hline $\mathrm{R}_{\mathrm{L}}$ & 0.7104 & - \\
\hline $\mathrm{k}_{\mathrm{F}}(\mathrm{mg} / \mathrm{g})$ & - & 5.5428 \\
\hline $\mathrm{n}_{\mathrm{F}}$ & - & 2.3068 \\
\hline $\mathrm{R}^{2}$ & 0.9814 & 0.9485 \\
\hline
\end{tabular}

Table 3. Biosorption capacities of various biosorbents investigated for the removal of CPX from aqueous solutions.

\begin{tabular}{|c|c|c|}
\hline Biosorbent & Maximum Biosorption Capacity, $Q_{\mathrm{m}}[\mathrm{mg} / \mathrm{g}]$ & References \\
\hline Chlorella sp., biomass (non-living) & 63.29 & [44] \\
\hline $\begin{array}{c}\text { Bacterial consortium biomass Burkholderia cepacia, } \\
\text { Chryseomonas luteola, Pseudomonas fluorescens, Bacillus subtilis, } \\
\text { Bacillus megaterium, Bacillus stearothermophilus, Citrobacter } \\
\text { freundii, Kluyvera spp. (living) }\end{array}$ & 10.61 & [43] \\
\hline \multicolumn{3}{|l|}{$\begin{array}{c}\text { Mixed bacterial cell biomass (Bacteria genus: Bacillus, } \\
\text { Pseudomonas, Burkholderia, Chryseomonas, } \\
\text { Citrobacter, Klyuvera) }\end{array}$} \\
\hline $\begin{array}{ll}- & \text { living } \\
\text { - } & \text { non-living }\end{array}$ & $\begin{array}{l}60 \\
30\end{array}$ & [45] \\
\hline \multicolumn{3}{|l|}{ Mixed Gram-positive bacteria (Bacillus genus) } \\
\hline $\begin{array}{ll}- & \text { living } \\
- & \text { non-living }\end{array}$ & $\begin{array}{l}50.91 \\
15.99\end{array}$ & \\
\hline \multicolumn{3}{|l|}{$\begin{array}{c}\text { Mixed Gram-negative bacteria (bacteria genus: Pseudomonas, } \\
\text { Burkholderia, Chryseomonas, Citrobacter, Klyuvera) }\end{array}$} \\
\hline $\begin{array}{ll}- & \text { living } \\
- & \text { non-living }\end{array}$ & $\begin{array}{l}40.44 \\
25.11\end{array}$ & \\
\hline Bacillus subtilis strain (living) & 27.22 & [46] \\
\hline $\begin{array}{l}\text { Saccaromyces cerevisiae immobilized in calcium } \\
\text { alginate beads }\end{array}$ & 94.34 & Present study \\
\hline
\end{tabular}

The Langmuir model also serves to establish the value of the separation factor $\left(R_{L}\right)$ which reveals if the biosorption is irreversible $\left(R_{L}=0\right)$, linear $\left(R_{L}=1\right)$, favorable $\left(0<R_{L}<1\right)$, or unfavorable $\left(R_{L}>1\right)$ [34]. Our calculated $R_{L}$ is 0.7104 indicating a favorable CPX elimination process.

In the case of the Freundlich model, $\mathrm{k}_{\mathrm{F}}$ and $\mathrm{n}$ constants give details on the amount of $\mathrm{CPX}$ adsorbed on biosorbent surface and on the biosorption intensity. The $\mathrm{k}_{\mathrm{F}}$ value suggests a favorable biosorption. This fact is in a good agreement with the results of Yadav et al. [58], who synthesized a new polymeric material and used it to eliminate different dyes, drugs and metals from the water matrix. 


\section{Conclusions}

The biosorbent Saccharomyces cerevisiae immobilized in calcium alginate composite beads was successfully synthesized. It had a mesoporous structure and the microorganism was homogeneously distributed in the polymer matrix, confirming that the immobilization process took place. This aspect is confirmed by results of SEM and FTIR analysis.

The best biosorption efficiency for CPX was obtained at an acidic $\mathrm{pH}$ (four), a fact explained by the biosorbent mesoporous structure, the $\mathrm{pH}_{\mathrm{PZC}}$ value of 6.6 and the zwitterionic form of $\mathrm{CPX}$ at this $\mathrm{pH}$ value.

Biosorption studies of CPX on Saccharomyces cerevisiae immobilized in calcium alginate beads indicate that the pseudo-second-order kinetic model is best suited to describe the process of kinetics.

The isotherms analysis evidenced that the CPX biosorbent interaction has a good fit for the Langmuir model with a correlation coefficient of 0.9814 and a maximum biosorption capacity of $94.34 \mathrm{mg} / \mathrm{g}$.

The findings of this study indicate that immobilization technique leads to obtain the biosorbents based on microorganisms which are easy to handle, stable, low-cost, ecofriendly and have the potential to be applied in the treatment of drugs-contaminated water or wastewater treatment plant effluents.

Author Contributions: Conceptualization, L.R. and C.-G.G.; methodology, E.M.S., C.-G.G., L.R. and A.-I.S.; software, A.-I.S.; validation, L.R., C.-G.G. and A.-I.S.; formal analysis, E.M.S., L.R. and C.-G.G.; investigation, E.M.S., L.R. and C.-G.G.; resources, L.R; writing-original draft preparation, L.R., A.-I.S., E.M.S. and C.-G.G.; writing-review and editing, L.R. and C.-G.G.; supervision, L.R., M.H. and D.S.; project administration, L.R. and D.S,.; funding acquisition, L.R. and D.S. All authors have read and agreed to the published version of the manuscript.

Funding: This research was funded by a grant of the Romanian Ministry of Research and Innovation, CCCDI-UEFISCDI, project number PN-III-P2-2.1-PED-2019-1063, within PNCDI III and the APC was funded by a grant of the Romanian Ministry of Research and Innovation, CCCDI-UEFISCDI, project number PN-III-P2-2.1-PED-2019-1063, within PNCDI III.

Data Availability Statement: All data produced in this study are presented in this paper.

Conflicts of Interest: The authors declare no conflict of interest. The funders had no role in the design of the study; in the collection, analyses, or interpretation of data; in the writing of the manuscript, or in the decision to publish the results.

\section{References}

1. Bouhedda, M.; Lefnaoui, S.; Rebouh, S.; Yahoum, M.M. Predictive model based on Adaptive Neuro-Fuzzy Inference System for estimation of Cephalexin adsorption on the Octenyl Succinic Anhydride starch. Chemom. Intell. Lab. Syst. 2019, $193,103843$. [CrossRef]

2. Grisales-Cifuentes, C.M.; Serna Galvis, E.A.; Porras, J.; Flórez, E.; Torres-Palma, R.A.; Acelas, N. Kinetics, isotherms, effect of structure, and computational analysis during the removal of three representative pharmaceuticals from water by adsorption using a biochar obtained from oil palm fiber. Bioresour. Technol. 2021, 326, 124753. [CrossRef]

3. Cheng, N.; Wang, B.; Wu, P.; Lee, X.; Xing, Y.; Chen, M.; Gao, B. Adsorption of emerging contaminants from water and wastewater by modified biochar: A review. Environ. Pollut. 2021, 273, 116448. [CrossRef]

4. Vrinceanu, N.; Hlihor, R.M.; Simion, A.I.; Rusu, L.; Fekete-Kertész, I.; Barka, N.; Favier, L. New Evidence of the Enhanced Elimination of a Persistent Drug Used as a Lipid Absorption Inhibitor by Advanced Oxidation with UV-A and Nanosized Catalysts. Catalysts 2019, 9, 761. [CrossRef]

5. Favier, L.; Simion, A.I.; Rusu, L.; Pacala, M.L.; Grigoraş, C.-G.; Bouzaza, A. Removal of an organic refractory compound by photocatalysis in batch reactor-A kinetic study. Environ. Eng. Manag. J. 2015, 14, 1327-1338. [CrossRef]

6. Kadmi, Y.; Favier, L.; Simion, A.I.; Rusu, L.; Pacala, M.L.; Wolbert, D. Measurement of pollution levels of N-nitroso compounds of health concern in water using ultra-performance liquid chromatography-tandem mass spectrometry. Process. Saf. Environ. Prot. 2017, 108, 7-17. [CrossRef]

7. Kadmi, Y.; Favier, L.; Harja, M.; Simion, A.I.; Rusu, L.; Wolbert, D. A new strategy for pentachlorophenol monitoring in water samples using Ultra-High Performance Liquid Chromatography-Tandem Mass Spectrometry. Environ. Eng. Manag. J. 2015, 14, 567-574.

8. Sarmah, A.K.; Meyer, M.T.; Boxall, A.B.A. A global perspective on the use, sales, exposure pathways, occurrence, fate and effects of veterinary antibiotics (VAs) in the environment. Chemosphere 2006, 65, 725-759. [CrossRef] 
9. Favier, L.R.L.; Simion, A.I.; Hlihor, R.M.; Pacala, M.L.; Augustyniak, A. Efficient degradation of clofibric acid by heterogeneous photocatalytic oxidation process. Environ. Eng. Manag. J. 2019, 18, 1683-1692. [CrossRef]

10. Favier, L.; Harja, M.; Simion, A.I.; Rusu, L.; Kadmi, Y.; Pacala, M.L.; Bouzaza, A. Advanced oxidation process for the removal of chlorinated phenols in aqueous suspensions. J. Environ. Prot. Ecol. 2016, 17, 1132-1141.

11. Botero-Coy, A.M.; Martínez-Pachón, D.; Boix, C.; Rincón, R.J.; Castillo, N.; Arias-Marín, L.P.; Manrique-Losada, L.; Torres-Palma, R.; Moncayo-Lasso, A.; Hernández, F. An investigation into the occurrence and removal of pharmaceuticals in Colombian wastewater'. Sci. Total. Environ. 2018, 642, 842-853. [CrossRef]

12. Krzeminski, P.; Tomei, M.C.; Karaolia, P.; Langenhoff, A.; Almeida, C.M.R.; Felis, E.; Gritten, F.; Andersen, H.R.; Fernandes, T.; Manaia, C.M.; et al. Performance of secondary wastewater treatment methods for the removal of contaminants of emerging concern implicated in crop uptake and antibiotic resistance spread: A review. Sci. Total. Environ. 2019, 648, 1052-1081. [CrossRef]

13. Krasucka, P.; Pan, B.; Sik Ok, Y.; Mohan, D.; Sarkar, B.; Oleszczuk, P. Engineered biochar-A sustainable solution for the removal of antibiotics from water. Chemical Eng. J. 2021, 405, 126926. [CrossRef]

14. Ali Noman, E.; Al-Gheethi, A.; Saphira Radin Mohamed, R.M.; Talip, B.A.; Hossain, M.S.; Ali Hamood Altowayti, W.; Ismail, N. Sustainable approaches for removal of cephalexin antibiotic from non-clinical environments: A critical review. J. Hazard. Mater. 2021, 417, 126040. [CrossRef] [PubMed]

15. Wang, B.; Li, H.; Liu, T.; Guo, J. Enhanced removal of cephalexin and sulfadiazine in nitrifying membrane-aerated biofilm reactors. Chemosphere 2021, 263, 128224. [CrossRef] [PubMed]

16. Nazari, G.; Abolghasemi, H.; Esmaieli, M. Batch adsorption of cephalexin antibiotic from aqueous solution by walnut shell-based activated carbon. J. Taiwan. Institute. Chem. Eng. 2016, 58, 357-365. [CrossRef]

17. Minh, T.B.; Leung, H.W.; Loi, I.H.; Chan, W.H.; So, M.K.; Mao, J.Q.; Choi, D.; Lam, J.C.W.; Zheng, G.; Martin, M.; et al. Antibiotics in the Hong Kong metropolitan area: Ubiquitous distribution and fate in Victoria Harbour. Mar. Pollut. Bull. 2009, 58, 1052-1062. [CrossRef] [PubMed]

18. Gulkowska, A.; Leung, H.W.; So, M.K.; Taniyasu, S.; Yamashita, N.; Yeung, L.W.Y.; Richardson, B.J.; Lei, A.P.; Giesy, J.P.; Lam, P.K.S. Removal of antibiotics from wastewater by sewage treatment facilities in Hong Kong and Shenzhen, China. Water Res. 2008, 42, 395-403. [CrossRef]

19. Watkinson, A.J.; Murby, E.J.; Kolpin, D.W.; Costanzo, S.D. The occurrence of antibiotics in an urban watershed: From wastewater to drinking water. Sci. Total. Environ. 2009, 407, 2711-2723. [CrossRef]

20. Chen, Y.; Chen, H.; Zhang, L.; Jiang, Y.; Gin, K.Y.-H.; He, Y. Occurrence, Distribution, and Risk Assessment of Antibiotics in a Subtropical River-Reservoir System. Water 2018, 10, 104. [CrossRef]

21. Rodriguez-Mozaz, S.; Vaz-Moreira, I.; Varela Della Giustina, S.; Llorca, M.; Barceló, D.; Schubert, S.; Berendonk, T.U.; MichaelKordatou, I.; Fatta-Kassinos, D.; Martinez, J.L.; et al. Antibiotic residues in final effluents of European wastewater treatment plants and their impact on the aquatic environment. Environ. Int. 2020, 140, 105733. [CrossRef]

22. Meng, L.; Wang, J.; Li, X.; Cui, F. Insight into effect of high-level cephalexin on fate and driver mechanism of antibiotics resistance genes in antibiotic wastewater treatment system. Ecotoxicol. Environ. Saf. 2020, 201, 110739. [CrossRef] [PubMed]

23. Khanday, W.A.; Ahmed, M.J.; Okoye, P.U.; Hummadi, E.H.; Hameed, B.H. Single-step pyrolysis of phosphoric acid-activated chitin for efficient adsorption of cephalexin antibiotic. Bioresour. Technol. 2019, 280, 255-259. [CrossRef] [PubMed]

24. Basturk, I.; Varank, G.; Murat-Hocaoglu, S.; Yazici-Guvenc, S.; Can-Güven, E.; Oktem-Olgun, E.E.; Canli, O. Simultaneous degradation of cephalexin, ciprofloxacin, and clarithromycin from medical laboratory wastewater by electro-Fenton process. J. Environ. Chem. Eng. 2021, 9, 104666. [CrossRef]

25. He, J.; Zhang, Y.; Guo, Y.; Rhodes, G.; Yeom, J.; Li, H.; Zhang, W. Photocatalytic degradation of cephalexin by ZnO nanowires under simulated sunlight: Kinetics, influencing factors, and mechanisms. Environ. Int. 2019, 132, 105105. [CrossRef]

26. Tavasol, F.; Tabatabaie, T.; Ramavandi, B.; Amiri, F. Photocatalyst production from wasted sediment and quality improvement with titanium dioxide to remove cephalexin in the presence of hydrogen peroxide and ultrasonic waves: A cost-effective technique. Chemosphere 2021, 284, 131337. [CrossRef]

27. Tavasol, F.; Tabatabaie, T.; Ramavandi, B.; Amiri, F. Design a new photocatalyst of sea sediment/titanate to remove cephalexin antibiotic from aqueous media in the presence of sonication/ultraviolet/hydrogen peroxide: Pathway and mechanism for degradation. Ultrason. Sonochem. 2020, 65, 105062. [CrossRef]

28. Liu, H.; Liu, W.; Zhang, J.; Zhang, C.; Ren, L.; Li, Y. Removal of cephalexin from aqueous solutions by original and Cu(II)/Fe(III) impregnated activated carbons developed from lotus stalks Kinetics and equilibrium studies. J. Hazard. Mater. 2011, 185, 1528-1535. [CrossRef]

29. Pouretedal, H.R.; Sadegh, N. Effective removal of Amoxicillin, Cephalexin, Tetracycline and Penicillin G from aqueous solutions using activated carbon nanoparticles prepared from vine wood. J. Water Process. Eng. 2014, 1, 64-73. [CrossRef]

30. Miao, M.-S.; Liu, Q.; Shu, L.; Wang, Z.; Liu, Y.-Z.; Kong, Q. Removal of cephalexin from effluent by activated carbon prepared from alligator weed: Kinetics, isotherms, and thermodynamic analyses. Process. Saf. Environ. Prot. 2016, 104, 481-489. [CrossRef]

31. Shirani, Z.; Song, H.; Bhatnagar, A. Efficient removal of diclofenac and cephalexin from aqueous solution using Anthriscus sylvestris-derived activated biochar. Sci. Total. Environ. 2020, 745, 140789. [CrossRef]

32. Rashtbari, Y.; Hazrati, S.; Afshin, S.; Fazlzadeh, M.; Vosoughi, M. Data on cephalexin removal using powdered activated carbon (PPAC) derived from pomegranate peel. Data. Brief. 2018, 20, 1434-1439. [CrossRef] 
33. Ahmed, M.J.; Theydan, S.K. Adsorption of cephalexin onto activated carbons from Albizia lebbeck seed pods by microwaveinduced $\mathrm{KOH}$ and $\mathrm{K} 2 \mathrm{CO} 3$ activations. Chem. Eng. J. 2012, 211, 200-207. [CrossRef]

34. Rashtbari, Y.; Hazrati, S.; Azari, A.; Afshin, S.; Fazlzadeh, M.; Vosoughi, M. A novel, eco-friendly and green synthesis of PPAC$\mathrm{ZnO}$ and PPAC-nZVI nanocomposite using pomegranate peel: Cephalexin adsorption experiments, mechanisms, isotherms and kinetics. Adv. Powder Technol. 2020, 31, 1612-1623. [CrossRef]

35. Bangari, R.S.; Sinha, N. Adsorption of tetracycline, ofloxacin and cephalexin antibiotics on boron nitride nanosheets from aqueous solution. J. Mol. Liq. 2019, 293, 111376. [CrossRef]

36. Al-Gheethi, A.; Noman, E.; Saphira, R.M.R.M.; Talip, B.; Vo, D.-V.N.; Algaifi, H.A. Cephalexin removal by a novel Cu-Zn bionanocomposite biosynthesized in secondary metabolic products of Aspergillus arenarioides EAN603 with pumpkin peels medium: Optimization, kinetic and artificial neural network models. J. Hazard. Mater. 2021, 419, 126500. [CrossRef]

37. Wu, H.; Feng, Q.; Yang, H.; Alam, E.; Gao, B.; Gu, D. Modified biochar supported Ag/Fe nanoparticles used for removal of cephalexin in solution: Characterization, kinetics and mechanisms. Colloids. Surf. A: Physicochem. Eng. Asp. 2017, 517, 63-71. [CrossRef]

38. Mohseni-Bandpi, A.; Al-Musawi, T.J.; Ghahramani, E.; Zarrabi, M.; Mohebi, S.; Vahed, S.A. Improvement of zeolite adsorption capacity for cephalexin by coating with magnetic Fe3O4 nanoparticles. J. Mol. Liq. 2016, 218, 615-624. [CrossRef]

39. Samarghandi, M.R.; Al-Musawi, T.J.; Mohseni-Bandpi, A.; Zarrabi, M. Adsorption of cephalexin from aqueous solution using natural zeolite and zeolite coated with manganese oxide nanoparticles. J. Mol. Liq. 2015, 211, 431-441. [CrossRef]

40. Maharana, M.; Sen, S. Magnetic zeolite: A green reusable adsorbent in wastewater treatment. Mater. Today $2021,2,21$.

41. Zhao, Y.; Zhao, H.; Zhao, X.; Qu, Y.; Liu, D. Synergistic effect of electrostatic and coordination interactions for adsorption removal of cephalexin from water using a zirconium-based metal-organic framework. J. Coll. Inter. Sci. 2020, 580, 256-263. [CrossRef] [PubMed]

42. Rai, P.; Singh, K.P. Valorization of Poly (ethylene) terephthalate (PET) wastes into magnetic carbon for adsorption of antibiotic from water: Characterization and application. J. Environ. Manag. 2018, 207, 249-261. [CrossRef]

43. Al-Gheethi, A.A.; Efaq, A.N.; Mohamed, R.M.; Norli, I.; Kadir, M.O. Potential of bacterial consortium for removal of cephalexin from aqueous solution. J. Assoc. Arab. Univ. Basic. Appl. Sci. 2017, 24, 141-148. [CrossRef]

44. Angulo, E.; Bula, L.; Mercado, I.; Montaño, A.; Cubillán, N. Bioremediation of Cephalexin with non-living Chlorella sp., biomass after lipid extraction. Biores. Technol. 2018, 257, 17-22. [CrossRef]

45. Al-Gheethi, A.A.S.; Norli, I.; Lalung, J.; Megat, A.A.; Nur, F.Z.A.; Kadir, M.O.A. Biosorption of heavy metals and cephalexin from secondary effluents by tolerant bacteria. Clean. Technol. Environ. Policy 2014, 16, 137-148. [CrossRef]

46. Adel, A.S.; Lalung, J.; Efaq, A.N.; Ismail, N. Removal of cephalexin antibiotic and heavy metals from pharmaceutical effluents using Bacillus subtilis strain. Expert. Opin. Environ. Biol. 2015, 4, 2. [CrossRef]

47. Horciu, I.L.; Blaga, A.C.; Rusu, L.; Zaharia, C.; Suteu, D. Biosorption of reactive dyes from aqueous media using the Bacillus sp. residual biomass. Desalination. Water. Treat. 2020, 195, 353-360. [CrossRef]

48. De Rossi, A.; Rigueto, C.V.T.; Dettmer, A.; Colla, L.M.; Piccin, J.S. Synthesis, characterization, and application of Saccharomyces cerevisiae/alginate composites beads for adsorption of heavy metals. J. Environ. Chem. Eng. 2020, 8, 104009. [CrossRef]

49. Nunes, O.R.; Cordeiro, M.M.; de Oliveira, F.C.S.; Marques, P.T.; Quilty, B.; da Silva, M.; Thire, R.M.; McGuiness, G.B. FTIR analysis and quantification of phenols and flavonoids of five commercialy available plants extracts used in wound healing. Rev. Mater. 2016, 21, 767-779.

50. Das, T.K.; Scott, Q.; Bezbaruah, A.N. Montmorillonite-iron crosslinked alginate beads for aqueous phosphate removal. Chemosphere 2021, 281, 130837. [CrossRef] [PubMed]

51. Dilarri, G.; Corso, C.R. Saccharomyces cerevisiae immobilized onto cross-linked chitosan beads: Application of a novel material for the removal of dye toxicity. Environ. Technol. 2018, 39, 1851-1867. [CrossRef] [PubMed]

52. Abdelkrim, S.; Mokhtar, A.; Djelad, A.; Bennabi, F.; Souna, A.; Bengueddach, A.; Sassi, M. Chitosan/Ag-Bentonite Nanocomposites: Preparation, Characterization, Swelling and Biological Properties. J Inorg. Organomet. Polym. Mater. 2020, 30, 831-840. [CrossRef]

53. Bakatula, E.N.; Richard, D.; Neculita, C.M.; Zagury, G.J. Determination of point of zero charge of natural organic materials. Environ. Sci. Pollut. Res. 2018, 25, 7823-7833. [CrossRef]

54. Al-Khalisy, R.S.; Al-Haidary, A.M.A.; Al-Dujaili, A.H. Aqueous Phase Adsorption of Cephalexin onto Bentonite and Activated Carbon. Sep. Sci. Technol. 2010, 45, 1286-1294. [CrossRef]

55. Nazari, G.; Abolghasemi, H.; Esmaieli, M.; Sadeghi Pouya, E. Aqueous phase adsorption of cephalexin by walnut shell-based activated carbon: A fixed-bed column study. Appl. Sur. Sci. 2016, 375, 144-153. [CrossRef]

56. Wang, J.; Guo, X. Adsorption isotherm models: Classification, physical meaning, application and solving method. Chemosphere 2020, 258, 127279. [CrossRef]

57. Acelas, N.; Lopera, S.M.; Porras, J.; Torres-Palma, R.A. Evaluating the removal of the antibiotic cephalexin from aqueous solutions using an adsorbent obtained from palm oil fiber. Molecules 2021, 26, 3340. [CrossRef] [PubMed]

58. Yadav, S.; Asthana, A.; Singh, A.K.; Chakraborty, R.; Vidya, S.S.; Susan, M.A.B.H.; Carabineiro, S.A.C. Adsorption of cationic dyes, drugs and metal from aqueous solutions using a polymer composite of magnetic/ $\beta$-cyclodextrin/activated charcoal/Na alginate: Isotherm, kinetics and regeneration studies. J. Hazard. Mater. 2021, 409, 124840. [CrossRef] 